(c) American Dairy Science Association, 2007.

\title{
Characteristics of Reduced Fat Milks As Influenced By the Incorporation of Folic Acid
}

\author{
K. Achanta, C. A. Boeneke, ${ }^{1}$ and K. J. Aryana \\ School of Animal Sciences, Louisiana State University Agricultural Center, Baton Rouge 70803
}

\begin{abstract}
Folic acid plays an important role in the prevention of neural tube defects (e.g., spina bifida and anencephaly), heart defects, facial clefts, urinary abnormalities, and limb deficiencies. Milk and milk products serve as a potential source for folic acid fortification because of the presence of folate-binding proteins that seem to be involved in folate bioavailability. Although milk is not a good source of folic acid, fortification could help in the prevention of the above-mentioned defects. The objective of this study was to examine the physicochemical characteristics of reduced fat milks fortified with folic acid. Reduced fat milks were prepared using 25, 50, 75, and $100 \%$ of the recommended dietary allowance of 400 $\mu \mathrm{g}$ of folic acid. Treatments included addition of folic acid at these levels before and after pasteurization. Color, $\mathrm{pH}$, fat, protein, viscosity, folic acid concentration, folate-binding protein concentration, folate-binding protein profile, standard plate count, and coliform counts were determined on d $1,7,14$, and 21 . A consumer acceptability test was conducted on d 7. Data from the consumer panel were analyzed using ANOVA (PROC GLM) with means separation to determine the differences among treatments. Data obtained from the color, $\mathrm{pH}$, fat, protein, viscosity, folic acid concentration, folate-binding protein concentration, standard plate count, and coliform counts were analyzed using the GLM with a repeated measure in time. Significant differences were determined at $P<0.05$ using Tukey's Studentized Range Test. There were no differences in the electrophoretic mobility of folate-binding protein in the samples. The concentration of folic acid was significantly higher in reduced fat milks fortified with folic acid after pasteurization compared with the treatments in which folic acid was added before pasteurization. The consumer panelists did not find any significant differences in flavor, appearance, or texture of folic acid fortified reduced fat milks compared with that of the control. Fortification of reduced fat milks with folic acid
\end{abstract}

Received June 16, 2006.

Accepted August 14, 2006

${ }^{1}$ Corresponding author: cboene1@lsu.edu can be accomplished without adversely affecting the product characteristics.

Key words: folic acid, reduced fat milk, pasteurization

\section{INTRODUCTION}

Consumer demand exists for healthier products, which is evidenced by the growth of the functional food industry from $\$ 31.6$ billion in 1999 (Anonymous, 2000) to $\$ 55$ billion in 2001 (Nutrition Business Journal, 2002). Competition in the dairy industry is driving the fluid milk sector to improve the nutritional value and decrease the fat content of dairy products to enable them to compete with innovative products. As the production and consumption of low fat but nutritionally rich products increases, industry focuses on the importance of improving these products. Consumers expect fluid milk products to be healthy and nutritious. Low fat and nonfat dairy products are targeted toward people who are trying to lose weight and those with cardiovascular problems. There has been a tremendous increase in the sales of reduced and low fat milk from 15,918 million pounds in 1980 to 23,559 million pounds in 2003 (Milk Facts, 2004). Of the total fluid milk product sales in 2003, reduced and low fat milk accounted for $43.5 \%$ compared with $32.9 \%$ for whole milk and $14.41 \%$ for nonfat milk (Milk Facts, 2004).

Vitamins are essential for human health. Folic acid is one of the important vitamins that can cause severe negative health effects when deficient. Folic acid deficiency is responsible for neural tube defects such as anencephaly and spina bifida in humans (Czeizel, 1995). Folic acid is important in the nervous system at all ages, but in elderly people, deficiency leads to aging brain processes, increases the risk of Alzheimer's disease and vascular dementia and, if critically severe, can lead to reversible dementia (Reynolds, 2002).

Folic acid is a water-soluble vitamin and is known by several different names including folate, folacin, folacid, folbal, pteroylglutamic acid (PGA), pterol-L-glutamic acid, pterol-L-monoglutamic acid, and vitamin $\mathrm{B}_{9}$ (American Chemical Society, 2002). Folic acid is found in broccoli, spinach, romaine lettuce, dried beans, and liver (Wardlaw, 1999). Milk and milk products are not 
a good source of folic acid; cow's milk contains 5 to 7 $\mu \mathrm{g}$ of folic acid (Renner, 1983; Scott, 1989).

The US Centers for Disease Control (CDC) recommends that women of childbearing age consume 400 $\mu \mathrm{g}$ of folic acid daily to prevent neural tube defects (CDC 1993). The current recommended daily allowance (RDA) for children 1 to $3 \mathrm{yr}$ of age is $150 \mu \mathrm{g} / \mathrm{d}$; for children 4 to $13 \mathrm{yr}$ of age is $300 \mu \mathrm{g} / \mathrm{d}$; and for ages 14 to $>70 \mathrm{yr}$ is $400 \mu \mathrm{g} / \mathrm{d}$ (Food and Nutrition Board, 2002).

Folate-binding protein (FBP) exists as a minor whey protein in milk (Salter et al., 1981) that is crucial to the assimilation, distribution, and retention of folic acid (Davis and Nichol, 1988). Almost all naturally occurring folate in milk is bound to FBP (Ghitis et al., 1969). The FBP in bovine milk exists at concentrations of about $10 \mathrm{mg} / \mathrm{L}$ (Salter et al., 1972), and binds approximately 1 mole of folate per mole of protein at $\mathrm{pH} 7.2$ (Salter et al., 1981). The FBP from cow's milk has a molecular weight of $35,000 \pm 1,500$ daltons with a high proportion of half-cystine (18 residues/molecule) and $10.3 \%$ of carbohydrate (fucose, mannose, and galactose; Salter et al., 1981). Folate-binding protein is temperature stable; FBP isolated from whey powder obtained from milk vacuum evaporated at $68^{\circ} \mathrm{C}$ and spray dried at $180^{\circ} \mathrm{C}$ was able to bind $0.5 \mathrm{~mol}$ of folate/mol (Salter et al., 1981). Pasteurization of milk (at $72^{\circ} \mathrm{C}$ for $15 \mathrm{~s}$ ) is thought to result in heat-induced alteration of the FBP molecule (Gregory, 1982).

Folate-binding proteins in milk are interesting because they seem to be involved in bioavailability of folate (Verwei et al., 2003). Folate-binding proteins may protect folate from bacterial uptake and degradation (Ford, 1974). Adding folic acid to reduced fat milk may have additional health benefits. It is common practice to add vitamins $\mathrm{A}$ and $\mathrm{D}$ during fluid milk processing. The effects of direct addition of a water-soluble vitamin, folic acid, to reduced fat milk on the physicochemical and sensory characteristics are not known.

The objectives of this study were 1) to determine the effect of different concentrations of folic acid on the physicochemical and consumer acceptability of reduced fat milks over a 3-wk storage period; and 2) to elucidate the effect of the stage of addition of folic acid on the physicochemical and sensory characteristics of reduced fat milks over a 3 -wk storage period.

\section{MATERIALS AND METHODS}

\section{Experimental Design}

Reduced fat milks were fortified with folic acid at 25 , 50,75 , or $100 \%$ of the RDA of $400 \mu \mathrm{g}$ of folic acid per 236-mL serving. Folic acid was added before or after HTST pasteurization. Color $\left(\mathrm{L}^{*}, \mathrm{a}^{*}, \mathrm{~b}^{*}\right), \mathrm{pH}$, fat, protein, viscosity, folic acid concentration, FBP concentra- tion, FBP profile, SPC, and coliform counts of fortified milks were determined on $\mathrm{d} 1,7,14$, and 21 . A consumer acceptability test was conducted on $\mathrm{d} 7$. The experiment was conducted and analyzed as a randomized complete block with repeated measures. The replications were the blocks and 3 replications were conducted.

\section{Preparation of Reduced Fat Milks}

Raw whole milk (approximately $360 \mathrm{~L}$ ) was obtained from the Louisiana State University (LSU) dairy farm and held at $4^{\circ} \mathrm{C}$ until use $(<1 \mathrm{~h})$. Cream and skim milk at $4^{\circ} \mathrm{C}$ were separated using a DeLaval 392 Airtight Cream separator (Alfa Laval Inc., Richmond, VA). Reduced fat milk (2\% total fat) was prepared by adding an appropriate amount of cream to skim milk. Before pasteurization, pharmaceutical grade folic acid (Ampak Co., New York, NY) at 25, 50, 75, or $100 \%$ of the RDA of $400 \mu \mathrm{g}$ was added separately to 4 equal volumes of the reduced fat milk. Milks were then homogenized using a 2-stage homogenizer (APV Americas, Lake Mills, WI) at 12.4 and 3.4 MPa on the first and second stages, respectively, followed by pasteurization for 16 $\mathrm{s}$ at $72.5^{\circ} \mathrm{C}\left(163^{\circ} \mathrm{F}\right)$. Folic acid at $25,50,75$, or $100 \%$ of the RDA of $400 \mu \mathrm{g}$ was also added separately to 4 equal volumes of unfortified reduced fat milks after homogenization and pasteurization. Control was homogenized and pasteurized reduced fat milk.

\section{Analytical Procedures}

Folic Acid Concentration. Folic acid concentration was determined by using HPLC with methods modified from Albala-Hurtado et al. (1997). The HPLC system consisted of a Waters 501 pump, Waters 717 Plus autosampler, and Waters 486 tunable UV detector set at $282 \mathrm{~nm}$ (Waters Corp., Milford, MA). Peak areas were calculated using the Waters Millennium software. The separation was carried out isocratically using a Waters Spherisorb $5 \mu \mathrm{m}$ ODS2 4.6- $\times 250-\mathrm{mm}$ column with guard cartridge. Samples were prepared as follows: 10.5 $\mathrm{g}$ of the sample was weighed into a $50-\mathrm{mL}$ centrifuge tube with a screw-on cap, $1 \mathrm{~g}$ of crystalline TCA was added, and the mixture was shaken for $10 \mathrm{~min}$ on a mechanical shaker. The mixture was centrifuged at $1,250 \times \mathrm{g}$ for $10 \mathrm{~min}$. The supernatant was decanted to a $10-\mathrm{mL}$ volumetric flask and $3 \mathrm{~mL}$ of $4 \%$ (wt/vol) TCA was added to the solid phase. The mixture was shaken for $10 \mathrm{~min}$ and centrifuged again at $1,250 \times \mathrm{g}$ for 10 min. The supernatant was then added to the $10-\mathrm{mL}$ volumetric flask, and the flask wrapped in aluminum foil to protect it from light. Samples were filtered through a $45-\mu \mathrm{m}$ filter (Sigma Aldrich, St. Louis, MO) and placed in clear glass HPLC vials protected from 


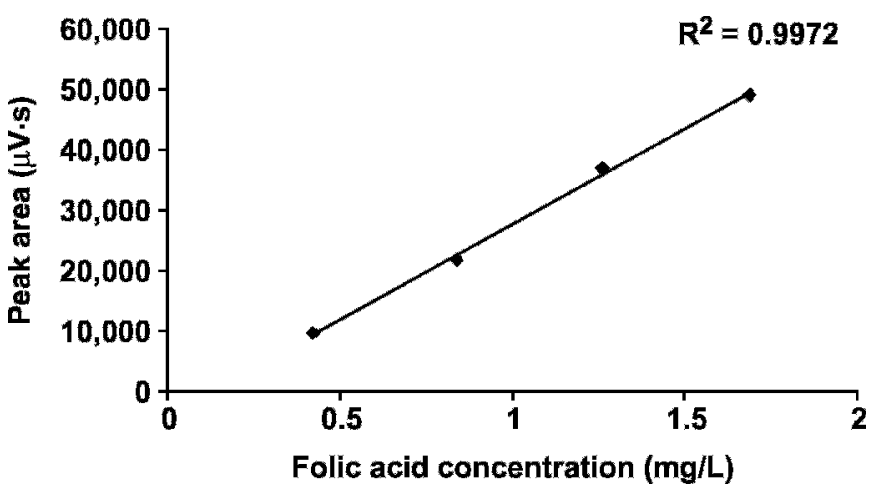

Figure 1. Standard curve of folic acid concentrations.

light with aluminum foil. Eluent was prepared as described in Albala-Hurtado et al. (1997). A standard curve (Figure 1) was prepared by quantifying 25,50 , 75 , and $100 \%$ RDA standards of folic acid in HPLCgrade double-distilled water. The $100 \%$ RDA standard was prepared by adding $1.69 \mathrm{mg}$ of folic acid to $1 \mathrm{~L}$ of HPLC-grade double-distilled water. The 75, 50, and 25\% RDA solutions were prepared by adding $75 \mathrm{~mL}$ of the $100 \%$ solution to $25 \mathrm{~mL}$ of HPLC-grade doubledistilled water; $50 \mathrm{~mL}$ of the $100 \%$ solution to $50 \mathrm{~mL}$ of HPLC-grade double-distilled water; and $25 \mathrm{~mL}$ of the $100 \%$ solution to $75 \mathrm{~mL}$ of HPLC-grade double-distilled water, respectively. A sample volume of $10 \mu \mathrm{L}$ was injected using an autosampler (Waters Corp.). Run time for samples was 20 min using a flow rate of $1 \mathrm{~mL} / \mathrm{min}$. These known concentrations of folic acid solutions were filtered through a $45-\mu \mathrm{m}$ filter (Sigma Aldrich), and injected using an autosampler. Under the conditions used in this experiment, folic acid is known to elute out of the column and be detected by the UV detector in 11 to $14 \mathrm{~min}$ at $280 \mathrm{~nm}$ (Albala-Hurtado et al., 1997). Folic acid peak areas corresponding to its known concentrations were used to construct a standard curve. Peak areas of folic acid in the milk samples were fitted to the standard curve and corresponding values (in $\mathrm{mg} /$ L) were recorded.

FBP Concentration. Quantification of total FBP was performed using an ELISA, according to HoierMadsen et al. (1986) with slight modifications. Folatebinding protein in reduced fat milk samples was extracted in Triton X-100 ( $\sim 30 \mathrm{~mL} / \mathrm{L})$. Antibody solution (10 mg of anti-FBP/L of carbonate buffer, $\mathrm{pH}$ 9.6) was used to coat a 96-well microtiter plate (Sigma Aldrich). Then, $100 \mu \mathrm{L}$ of the extracted and diluted sample was added. After a 30 -min incubation at $37^{\circ} \mathrm{C}$, the solution was discarded, and the plate was washed 4 times with NaCl-EDTA-Tris buffer $(0.15 M \mathrm{NaCl}, 0.05 M$ Tris, and $0.001 M$ EDTA, $\mathrm{pH}$ 7.4). One hundred microliters of goat antibovine FBP-horseradish peroxidase (US Bio-

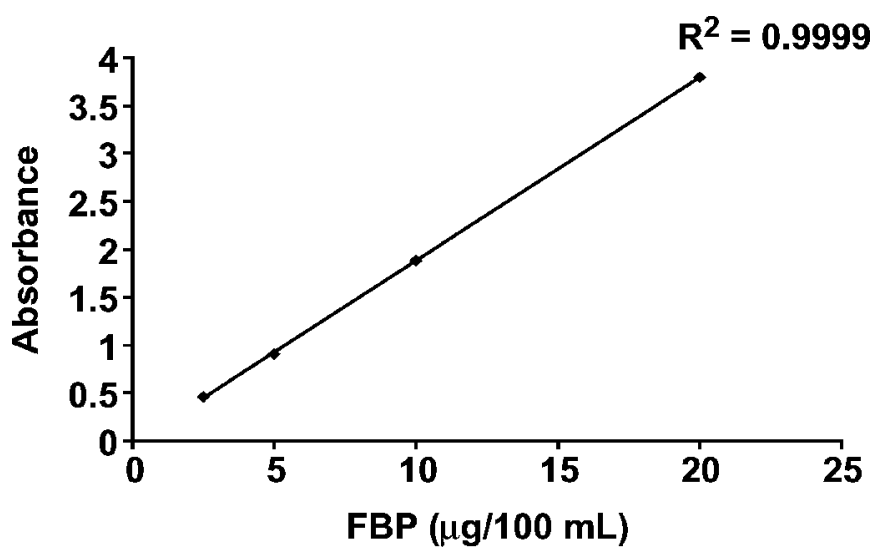

Figure 2. Standard curve of folate-binding protein (FBP) concentrations.

logical, Swampscott, MA) diluted 1:5,000 with assay buffer (NaCl-EDTA-Tris buffer + fish gelatin) was added and incubated for $1 \mathrm{~h}$ at $37^{\circ} \mathrm{C}$, protected from light by wrapping the microtiter plate in an aluminum foil. The solution was discarded and the plate was washed 4 times with NaCl-EDTA-Tris buffer. After washing, $100 \mu \mathrm{L}$ of ABTS Stable Liquid Substrate (US Biological) was added, and the reaction was stopped 10 min later with $2 \mathrm{M} \mathrm{H}_{2} \mathrm{SO}_{4}$. A standard curve (Figure 2) was obtained by using known concentrations (2.5, 5,10 , and $20 \mu \mathrm{g} / 100 \mu \mathrm{L}$ ) of bovine milk FBP antigen (Fitzgerald Industries International, Concord, MA). Sample FBP concentrations were derived from the standard curve of the purified bovine milk FBP plotted against the ratio of the relative absorption measured at $405 \mathrm{~nm}$ using an MRX Revelation Microplate reader (Dynex Technologies, Inc., Chantilly, VA). A blank was included in the assay.

FBP Profile. The FBP profile was studied by PAGE on a Novex XCell Mini Cell (Novex, San Diego, CA) using 4 to $12 \%$ NuPage gels (Novex). Samples were prepared by dissolving $0.2 \mathrm{~g}$ of reduced fat milk in 1 $\mathrm{mL}$ of distilled water; $27.9 \mu \mathrm{L}$ of this mixture was added to $31.1 \mu \mathrm{L}$ of distilled water and $25 \mu \mathrm{L}$ of $4 \times$ buffer containing $2 \%$ lithium dodecyl sulfate (Novex). Samples were heated in a $70^{\circ} \mathrm{C}$ water bath for $10 \mathrm{~min}$. Ten microliters of $10 \times$ reducing agent containing $500 \mathrm{~m} M$ dithiothreitol (Novex) was added to each sample. Samples were vortexed for $5 \mathrm{~s}$, and $20 \mu \mathrm{L}$ of each sample was loaded into each well of the gel. Twenty microliters of the broad-range prestained standards (BioRad Laboratories, Richmond, CA) and $20 \mu \mathrm{L}$ of FBP were also loaded to the wells separately. Running buffers were prepared by adding $50 \mathrm{~mL}$ of $3-\mathrm{N}$-morpholino propane sulfonic acid (MOPS) to $950 \mathrm{~mL}$ of distilled water; 600 $\mathrm{mL}$ was put in the lower, outer chamber, and $200 \mathrm{~mL}$ 


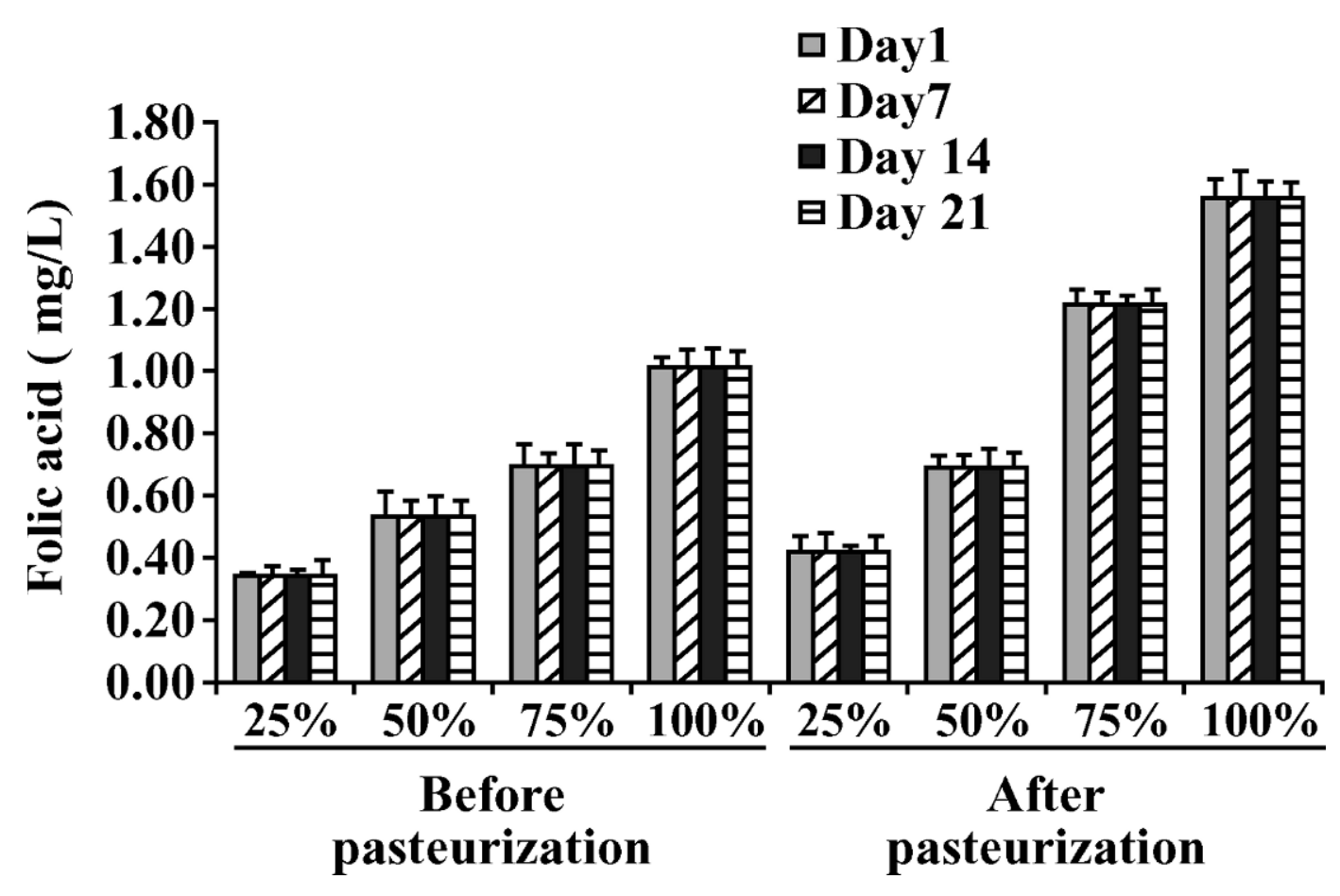

Figure 3. Mean $( \pm \mathrm{SE})$ concentration $(\mathrm{mg} / \mathrm{L})$ of folic acid in reduced fat milks at $25,50,75$, and $100 \%$ of recommended daily allowance added before or after pasteurization.

was placed in the upper chamber. Before the upper chamber was filled, $500 \mu \mathrm{L}$ of antioxidant (Novex) was added to the $200 \mathrm{~mL}$ of buffer solution. Two gels were run simultaneously at $400 \mathrm{~V}$ for $1 \mathrm{~h}$. Gels were taken out of the carriage and placed in staining trays containing $110 \mathrm{~mL}$ of distilled water, $40 \mathrm{~mL}$ of methanol, and $40 \mathrm{~mL}$ of stain A containing ammonium sulfate and phosphoric acid (Novex) for $10 \mathrm{~min}$, followed by addition of $10 \mathrm{~mL}$ of stain $\mathrm{B}$ (Novex). Gels were stained for 12 to $14 \mathrm{~h}$ followed by destaining in distilled water for 1 wk. Images were recorded using a Kodak CX4300 digital camera (Kodak, Rochester, NY).

Color. Color was determined by $\mathrm{L}^{*}, \mathrm{a}^{*}, \mathrm{~b}^{*}$ values using a Hunter MiniScan XE Plus portable color spectrophotometer (model no. 45/0-L, Hunter Associates Laboratory Inc., Reston, VA). Equipment was calibrated using the black and white tiles included with the instrument. Operating conditions were illuminant D65, $10^{\circ}$ observer value, reflectance mode, and $45 / 0$ sensor. An average of 5 readings per sample was recorded.

$\boldsymbol{p H}$. The $\mathrm{pH}$ was measured at $25^{\circ} \mathrm{C}$ using an Ultra Basic Bench top pH meter (Denver Instruments Company, Arvada, CO) that was calibrated before use by commercial $\mathrm{pH} 4.00$ and 7.00 standard buffers (Fisher Scientific, Hampton, NH).

Fat. Fat content was determined using Babcock's method according to Richardson (1985).
Protein. Protein content was determined using a Bentley 2000 Fat and Protein Analyzer (Bentley Instruments Inc., Chaska, MN) at the LSU Dairy Improvement Center (Baton Rouge).

Viscosity. Viscosity was measured at $21^{\circ} \mathrm{C}$ using a Brookfield DVII+ viscometer with helipath stand. The spindle used was a RV spindle disc set at $10 \mathrm{rpm}$. Data points (100 per sample) were collected using Wingather software (Brookfield Engineering Lab, Stoughton, MA). Viscosity readings were expressed in centipoise.

SPC. Standard plate counts $(\mathrm{cfu} / \mathrm{mL})$ were determined according to Richardson (1985). Aerobic Plate Count Petrifilms (3M, St. Paul, MN) were used to enumerate the bacteria in reduced fat milks. An incubation temperature of $32^{\circ} \mathrm{C}$ for $48 \mathrm{~h}$ was used.

Coliform Counts. Coliform counts (cfu/mL) were determined according to Richardson (1985). Coliform Count Plate Petrifilms (3M) were used to enumerate the coliforms in the reduced fat milks. An incubation temperature of $32^{\circ} \mathrm{C}$ for $24 \mathrm{~h}$ was used.

\section{Consumer Acceptability Testing}

The project was submitted to the LSU Agricultural Center IRB Review Board for review before consumer testing was conducted. Exemption was granted under proposal number HE03-12. Consumer acceptability testing was conducted in the sensory evaluation room 


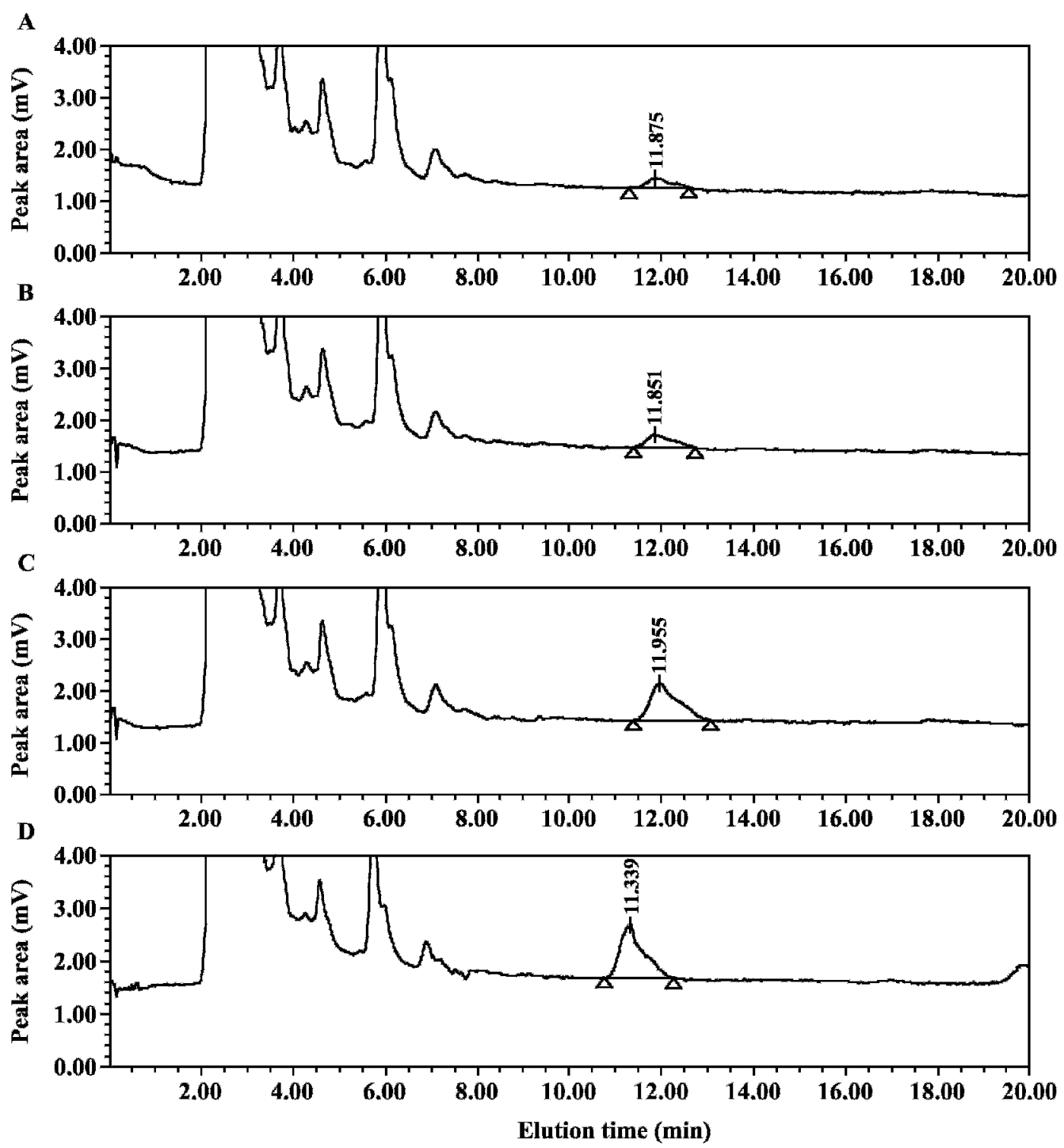

Figure 4. Peak area (HPLC) of reduced fat milks fortified with folic acid at 25\% (panels A and B) and 100\% (panels C and D) of recommended daily allowance (RDA) before (A and C) and after (B and D) pasteurization at d 1.

in the LSU Creamery on $d 7$ and 8 after preparing the reduced fat milks. Consumers $(n=180)$ evaluated overall acceptability, appearance, color, flavor, and texture/mouthfeel of reduced fat milks fortified with folic acid using a 9 -point hedonic scale $(1=$ dislike extremely, $5=$ neither dislike nor like, and $9=$ like extremely). A balanced incomplete block design (plan $11.3 \mathrm{a}$; treatments $(\mathrm{t})=9$; units per block $(\mathrm{k})=2$; replications $(\mathrm{r})=$ 8 ; total number of blocks $(\mathrm{b})=36$; number of times that 2 treatments appear together in a block $(\lambda)=1$; (efficiency) $\mathrm{E}=0.56$; type II (designs arranged in groups of replications) described by Cochran and Cox (1957) was used. This design allowed consumers to evaluate
2 out of 9 samples and provided the means to obtain consistent, reliable data.

\section{Statistical Analysis}

Data from the consumer panel was analyzed using ANOVA (PROC GLM) with means separation to determine the differences among treatments (Version 9.0, 2001; SAS Institute, Inc., Cary, NC). Significance was established at $P<0.05$ using Tukey's Studentized Range Test. Data obtained from the color, $\mathrm{pH}$, fat, protein, viscosity, folic acid concentration, FBP concentra- 


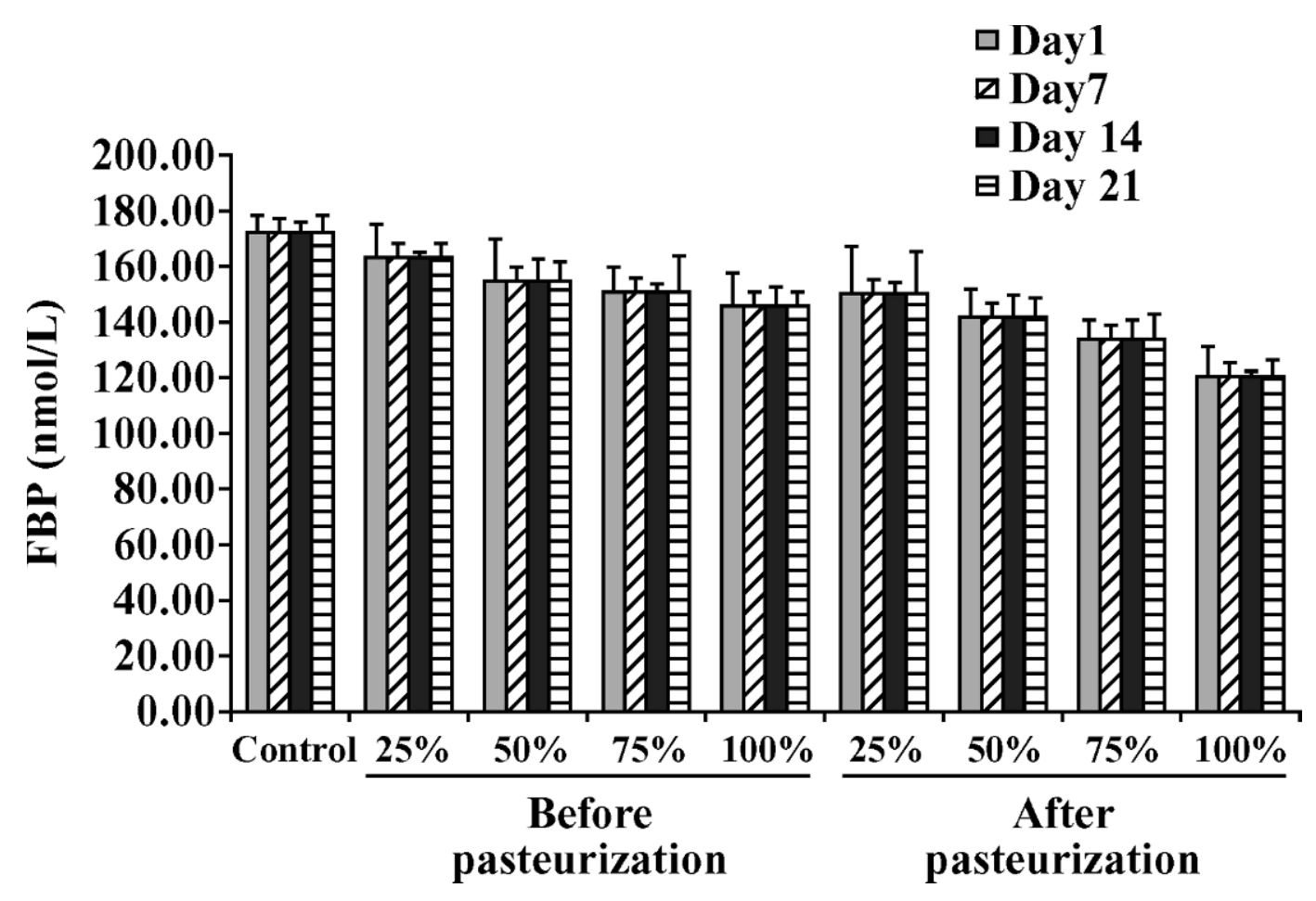

Figure 5. Mean $( \pm \mathrm{SE})$ concentrations $(\mathrm{nmol} / \mathrm{L})$ of folate-binding protein $(\mathrm{FBP})$ in reduced fat milks with folic acid at $25,50,75$, and $100 \%$ of recommended daily allowance (RDA) added before or after pasteurization.

tion, SPC, and coliform counts were analyzed using the GLM with a repeated measure in time.

\section{RESULTS AND DISCUSSION}

\section{Folic Acid Concentration}

Folic acid concentrations as peak areas are reported in Figure 3. There were no significant $(P>0.05)$ differences among overall mean peak areas on $\mathrm{d} 1,7,14$, and 21 , indicating no significant $(P>0.05)$ losses of folic acid concentration over the storage period. Anderson and Oste (1994) reported that folate levels in pasteurized milk were not reduced during storage beyond the expiration date.

The HPLC chromatographs from d 1 of $25 \%$ RDA samples before and after pasteurization and 100\% RDA samples before and after pasteurization are reported in Figure 4 (panels A, B, C, and D, respectively). Significant differences $(P<0.05)$ were found in overall level of folic acid addition. Peak areas increased proportionally as folic acid levels increased. Amount of folic acid added before vs. after pasteurization affected mean peak area values. Mean values were lower for folic acid added before pasteurization, indicating that pasteurization has an effect on the folic acid. Groff and Grooper (1998) reported folic acid losses on cooking.

\section{FBP Concentration}

Folate-binding protein concentrations obtained from ELISA are reported in Figure 5. There was no treatment $x$ time interaction. Time was found to have no significant $(P>0.05)$ effect on the FBP concentration of the samples. Pasteurization had no significant $(P>$ $0.05)$ effect on the FBP content. There was a significant $(P<0.05)$ difference in the level of folic acid addition and the mean FBP values of the samples. The FBP values decreased significantly $(P<0.05)$ as the concentration of folic acid increased. The probable reason for the decrease in the values of FBP with the increase in the folic acid concentration may be attributed to the binding of folic acid to FBP, which may have prevented it from reacting with the antibody to produce color during ELISA. Ghitis et al. (1969) reported that binding of pteroylglutamate (folic acid) is quantitative, rapid, and irreversible, and is not dependent on temperature or pH. Salter et al. (1981) observed that the soluble FBP of cow's milk could bind $1 \mathrm{~mol}$ of folate/mol of FBP. Verwei et al. (2003) reported that the FBP concentration of the milk is inversely proportional to the free folic acid fractions, which means that FBP concentration decreases as the concentration of free folic acid increases. Salter et al. (1981) reported the FBP isolated from whey powder obtained from milk vacuum evapo- 


\section{kDa}

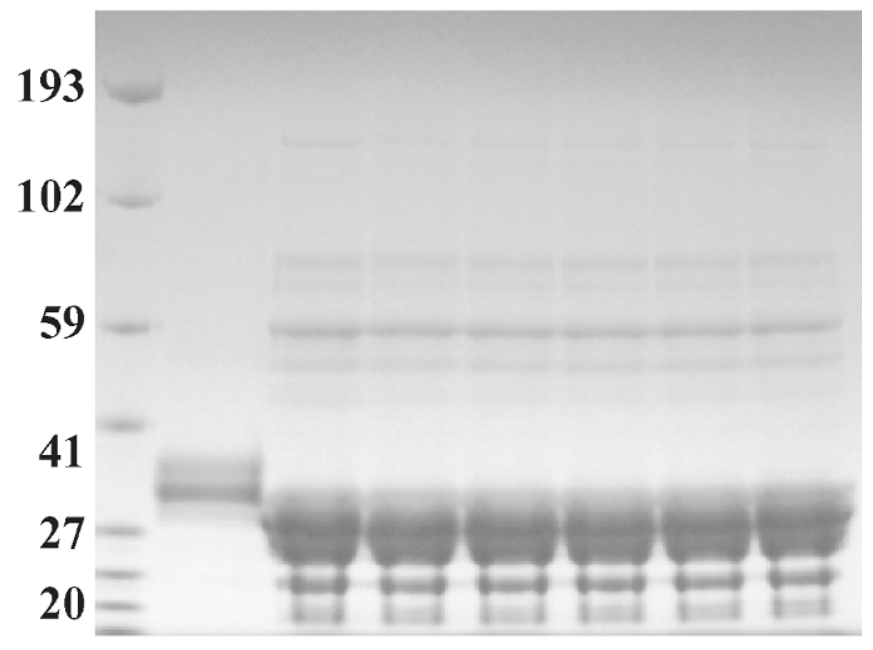

$\begin{array}{llllllll}\text { Std } & 1 & 2 & 3 & 4 & 5 & 6 & 7\end{array}$

Figure 6. Polyacrylamide gel electrophoresis of reduced fat milks with folic acid added before and after pasteurization at 75 and $100 \%$ of recommended daily allowance (RDA) on d 21. Std = molecular weight standard; lane 1 = folate-binding protein standard; lane $2=$ raw milk; lane $3=$ control; lane $4=$ folic acid added at $75 \%$ RDA before pasteurization; lane $5=$ folic acid added at $75 \%$ RDA after pasteurization; lane $6=$ folic acid added at $100 \%$ RDA before pasteurization; lane 7 = folic acid added at $100 \% \mathrm{RDA}$ after pasteurization.

rated at $68^{\circ} \mathrm{C}$ and spray-dried at $180^{\circ} \mathrm{C}$ was able to bind $0.5 \mathrm{~mol}$ of folate/mol. Gregory (1982) reported that pasteurization of milk (at $72^{\circ} \mathrm{C}$ for $15 \mathrm{~s}$ ) resulted in heat-induced alterations of the FBP molecule. This experiment showed the FBP in pasteurized milk was able to bind added folic acid. Verwei et al. (2003) reported that FPB was involved in bioavailability of folate. Folate-binding protein may protect folate from bacterial uptake and degradation (Ford, 1974). The FBP in milk may help added folic acid to be more bioavailable.

\section{FBP Profile}

Analysis with PAGE indicated no differences in FBP migration patterns over the storage period with addition of all 4 levels of folic acid. Folate-binding protein bands in all samples showed separations at around 35 $\mathrm{kDa}$ (Figure 6). The FBP from cow's milk has a molecular weight of $35,000 \pm 1,500$ with a high proportion of half-cystine (18 residues/molecule) and about $10.3 \%$ carbohydrate (fucose, mannose, and galactose; Salter et al., 1981). Presence of FBP in the samples is clearly evident from the gels but the concentration of FBP could not be determined using gel electrophoresis. Results of ELISA (Figure 5) indicated that the FBP concentration decreased with the increase in folic acid concentration, but the gels did not show any variation in FBP concentration.

\section{Color}

There was no significant $(P>0.05)$ treatment $\times$ time interaction or pasteurization effect on mean $L^{*}$ (lightness), a* (green to red), and $b^{*}$ (yellowness) values. There was no significant $(P>0.05)$ difference in the concentration of folic acid added and the mean $\mathrm{L}^{*}$ or a* values of the samples; however, there were significant $(P<0.05)$ differences in concentration of folic acid added and the mean $b^{*}$ (yellowness) values. The mean $b^{*}$ (yellowness) values increased with increasing concentration of folic acid. The increase in the mean $b^{*}$ (yellowness) values can be attributed to the yellow color of the folic acid.

\section{pH}

The mean $\mathrm{pH}$ values ranged from 6.8 to 7.5. Time overall was found to be significant $(P<0.05)$. This may be due to the bacterial growth over the evaluation period (Figure 7). There were no significant $(P>0.05)$ differences in the $\mathrm{pH}$ values and concentration folic acid added before vs. after pasteurization. It was expected that folic acid addition might lower $\mathrm{pH}$ values; however, no such effect was observed.

\section{Fat and Protein Contents}

The mean fat and protein contents were constant at 2 and $2.6 \%$, respectively. There was no treatment $\times$ time interaction. Overall, there were no significant $(P$ $>0.05$ ) differences for pasteurization or for the concentration of folic acid addition. No significant $(P>0.05)$ differences were found overall on d 1, 7, 14, and 21 . The different concentrations of folic acid added had no effect on the fat and protein values of the samples.

\section{Viscosity}

Mean viscosity values were approximately $4.6 \mathrm{cp}$. There was no significant $(P>0.05)$ treatment $\times$ time interaction, pasteurization effect, or concentration effect on the viscosity values of samples. This is probably because the levels are too low to have any effect on product viscosity, even at $100 \%$ of RDA.

\section{SPC}

The mean values for SPC are reported in Figure 7. The SPC were not different among the treatments and an increase was observed during storage: SPC values 


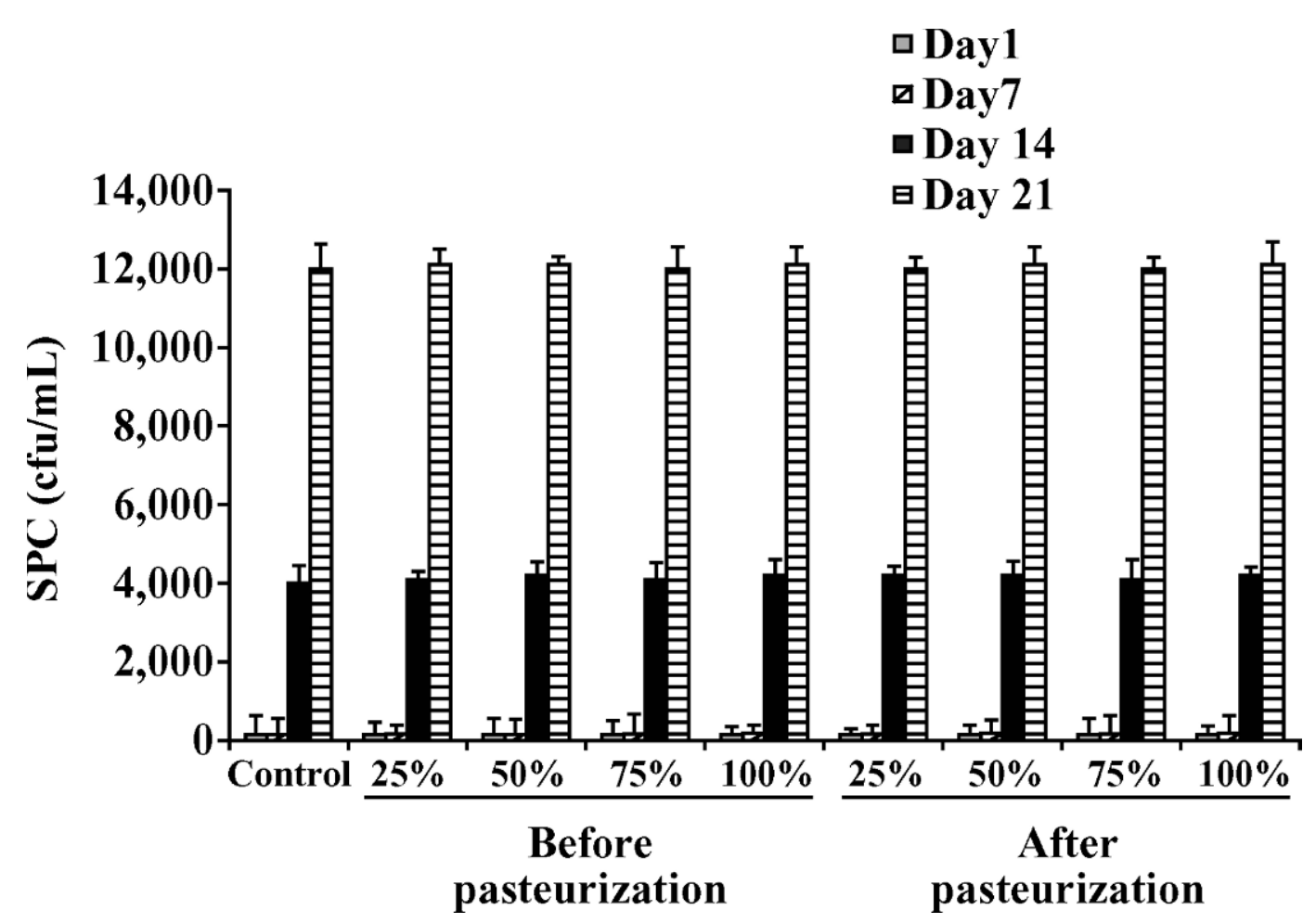

Figure 7. Mean SPC of reduced fat milks fortified with folic acid at 25, 50, 75, and 100\% of recommended daily allowance (RDA) added before or after pasteurization.

were higher on $\mathrm{d} 14$ and 21 compared with $\mathrm{d} 1$. Although the counts were the highest at $\mathrm{d} 21$, they were well within the legal limit of $20,000 \mathrm{cfu} / \mathrm{mL}$. A significant increase in the SPC during refrigerated storage can be evidence of a psychrotrophic microorganism's growth. Psychrotrophic microorganisms in milk cause spoilage by altering the constituents of milk (Cousin, 1982).

\section{Coliform Counts}

The coliform counts in all samples were $<10 \mathrm{cfu} / \mathrm{mL}$. No coliforms were detected during the storage period. This indicates that the heat treatment was effective and that there was no postpasteurization contamination. The presence of coliforms in pasteurized milk can be due to insufficient heat treatment (Raju and Nambutripad, 1987; Salji et al., 1988), or to contamination of a pasteurized product during packaging (Barnard, 1981; Burden et al., 1995).

\section{Consumer Acceptability}

Flavor, appearance, and texture/mouthfeel scores were evaluated on a hedonic scale from 1 to 9 . No significant $(P>0.05)$ differences were observed in folic acid addition before vs. after pasteurization or level of folic acid added. The mean flavor, appearance, and texture/mouthfeel scores were $7.75,8.15$, and 7.77 , respectively, indicating consumer acceptability of the samples.

\section{CONCLUSIONS}

Addition of folic acid before or after pasteurization at $25,50,75$, and $100 \%$ of the RDA $(400 \mu \mathrm{g})$ had no effect on the fat content, protein content, or viscosity of reduced fat milks. Pasteurization had an effect on the folic acid content. Mean folic acid content values appeared lower for folic acid added before pasteurization for the samples indicating that pasteurization has an effect on the folic acid. Results from ELISA indicated that the mean concentration of FBP in the samples decreased with the increase in the folic acid content. Analysis by PAGE indicated no differences in FBP migration patterns over the storage period with addition of all 4 levels of folic acid. Addition of folic acid to reduced fat milks before or after pasteurization did not affect flavor, appearance, or texture/mouthfeel scores. Fortification of reduced fat milks with folic acid can be accomplished without negatively affecting the product characteristics. 


\section{REFERENCES}

Albala-Hurtado, S., M. T. Vencianna-Nogues, M. Izquierdo-Pulido, and A. Marine-Font. 1997. Determination of water-soluble vitamins in infant milk by high performance liquid chromatography. J. Chromatogr. A. 778:247-253.

American Chemical Society. 2002. Registry number 59-30-3. American Chemical Society, Washington, DC.

Anderson, A., and R. Oste. 1994. Nutritional quality of pasteurized milk. Content of B12, folacin, and ascorbic acid during storage. Int. Dairy J. 4:161-172.

Anonymous. 2000. Euromonitor predicts healthy growth for world functional foods industry. Nutraceutical International 5:4.

Barnard, S. E. 1981. Correcting coliform problems of pasteurized milk. Dairy Food Sanit. 1:16-17.

Burden, P., P. Stross, N. J. Andrews, and M. H. Greenwood. 1995. Factors affecting results obtained with European Community test for pasteurized milk sampled at the heat treatment establishment. Int. J. Food Microbiol. 26:177-186.

Centers for Disease Control and Prevention (CDC). 1993. Recommendations for use of folic acid to reduce number of spina bifida cases and other neural tube defects. J. Am. Med. Assoc. 269:1233-1238.

Cochran, W. G., and G. M. Cox. 1957. Experimental Designs. 2nd ed. John Wiley \& Sons, New York, NY.

Cousin, M. A. 1982. Presence and activity of psychrotrophic microorganisms in milk and dairy products: A review. J. Food Prot. 45:172-207.

Czeizel, A. E. 1995. Folic acid in the prevention of neural tube defects. J. Pediatr. Gastroenterol. Nutr. 20:4-16.

Davis, R. E., and D. J. Nichol. 1988. Folic acid. Int. J. Biochem. 20:133-139.

Food and Nutrition Board. 2002. Dietary reference intakes for thiamin, riboflavin, niacin, vitamin $\mathrm{B} 6$, folate, vitamin $\mathrm{B} 12$, pantothenic acid, biotin, and choline. Natl. Acad. Press, Washington, DC.

Ford, J. E. 1974. Some observations on the possible nutritional significance of vitamin B12- and folate-binding proteins in milk. Br. J. Nutr. 31:243-257.

Ghitis, J., F. Mandelbaum-Shavit, and N. Grossowicz. 1969. Binding of folic acid and derivatives in milk. Am. J. Clin. Nutr. 22:156-162.

Gregory, I. J. F. 1982. Denaturation of the folacin-binding protein in pasteurized milk products. J. Nutr. 112:1329-1338.
Groff, J. L., and S. S. Grooper. 1998. The water-soluble vitamins. Pages 289-298 in Advanced Nutrition and Human Metabolism. Wadsworth Thompson Learning. Belmont, CA.

Hoier-Madsen, M., S. I. Hansen, and J. Holm. 1986. Rabbit antibodies against the folate binding protein from cows' milk. Production, characterization and use for development of an enzyme-linked immunosorbent assay (ELISA). Biosci. Rep. 6:895-900.

Milk Facts. 2004. Sales and Production. Pages 83-84 in International Dairy Foods Association. Washington, DC.

Nutrition Business Journal. 2002. NBJ's functional food report. Pentoon Media Inc., San Diego, CA.

Raju, V. V. R., and V. K. N. Nambutripad. 1987. Incidence and growth of heat resistant coliform bacteria in milk and other media. Indian J. Dairy Sci. 40:354-358.

Renner, E. 1983. Milk and dairy products in human nutrition. VV Gmbh Volkswirtschaftlicher Verlag, Federal Republic of Germany.

Reynolds, E. H. 2002. Folic acid, ageing, depression, and dementia. Br. Med. J. 324:1512-1515.

Richardson, G. H. 1985. Standard Methods for the Examination of Dairy Products. 15th ed. Am. Public Health Assoc., Washington, DC.

Salji, J. S., S. R. Saadi, and A. Mashhadi. 1988. The shelf life of pasteurized fresh milk manufactured in Saudi Arabia. J. Food Prot. 51:976-978.

Salter, D. N., J. E. Ford, K. J. Scott, and P. Andrews. 1972. Isolation of the folate binding protein from cow's milk by the use of affinity chromatography. FEBS Lett. 20:302-306.

Salter, D. N., K. J. Scott, H. Slade, and P. Andrews. 1981. The preparation and properties of folate-binding protein from cow's milk. Biochem. J. 193:469-476.

SAS Institute. 2001. SAS Version 9.0. SAS Institute, Inc., Cary, NC.

Scott, K. J. 1989. Micronutrients in milk and milk based products. Pages 71-123 in Micronutrients in Milk and Milk-Based Food Products. Elsevier Applied Science, London.

Verwei, M., K. Arkbåge, R. Havenaar, H. van den Berg, C. Witthöft, and G. Schaafsma. 2003. Folic acid and 5-methyltetrahydrofolate in fortified milk are bioaccessible as determined in a dynamic in vitro gastrointestinal model. J. Nutr. 133:2377-2383.

Wardlaw, G. M. 1999. The water-soluble vitamins. Pages 290-327 in Perspectives in Nutrition. 4th ed. WCB/McGraw-Hill, New York, NY. 